\title{
Are you ready to vlog? A newly sophicticated way to improve students' speaking ability
}

\author{
Fitrotul Maulidiyah \\ Politeknik Negeri Malang, Indonesia \\ fitrotulmaulidiyah@polinema.ac.id \\ *) correspondence: fitrotulmaulidiyah@polinema.ac.id
}

\begin{abstract}
Students find it hard to speak English despite the fact that they have the basic knowledge of the language due to the lack of motivation and confidence. As the technology advances, teachers must be willing to take advantage of the potential channels provided by it. This study aims to improve students' motivation and confidence to speak English through the use of Vlog in the YouTube Channel as well as to find out the element that affect the most to the improvement of the motivation and confidence. The data were obtained through classroom observations, questionnaires and interviews. In terms of findings, this study revealed that the use of vlog in the YouTube Channel improved students' motivation and confidence. The data also suggested that students were most motivated and confident to speak English because they were given enough time to think of what they wanted to talk about and it was done in the place they found familiar. Therefore, teachers are suggested to bring technology into the classrooms more often and adjust it to the situation where students find it convenient to speak up.
\end{abstract}

Keywords: blogging; vlog; motivation; YouTube channel

\section{INTRODUCTION}

Blogging has turned into an exploding interest among the Internet communities these years. It has been an unavoidable tool among every element of people in daily life. As the world gets narrower, internet has become one responsible tool to changes occurring. As it could clearly be seen, internet performs significant roles in educational aspects in which many classes make use of internet in several kinds of instruments and activities.

In English classroom, one of the latest approaches inEnglish teaching and learning is through the integration of technology in the classroom environment (Mutmainna, 2016). For many years, internet has become one serious challenge of technology in people's lives. Through the use of internet, people could text, chat, browse, call and make video call. Through internet people could also empower themselves through sharing stories in their own sites. This activity is called blogging. "Weblogs" or "Blogs" or "Blogging" is a type of technology which allows people to writetheir personal journals online which can be published and viewed over the web (Mutmainna, 2016). In recent years, blogging has become an exploding passion among Internet communities (Gao, Tian, \& Huang, 2010). This blogging process is worldwide famous. From around 1997, blogging has become a quickly spreading passion among Internet literates (Parker \& Pfeiffer, 2005). It is also said that a blog entry is essentially a regular text entry into a web page in which people publish experiences, thoughts, and opinions. Nowadays, many people have their own personal blog as homepages.

Within the context of English as a foreign language (EFL), utilizing blogs has emerged as a language learning tool (Aydin, 2014). Furthermore, it has been stated by Aydin (2014) that the use of blogs plays a pivotal role in establishing interactions among students and between teachers and students in the target language. Blogs invite participation and have the potential to democratize a classroom since the learners are given the chance of equal participation (Mutmainna, 2016). Blogs 


\section{Fitrotul Maulidiyah}

are also beneficial. It is claimed that blogs work best when learners get into the habit of using them (Mutmainna, 2016). Many foreign educators have started applying this technology to classroom instruction and language learning too (Campbell, 2003; Johnson, 2004; Lankshear \& Knobel, 2003; Richardson, 2004, as cited in Mutmainna, 2016).

In relation with blogging, vlogging has become one prominent medium to visualize people's life. Videoblogging is the new trend in blogging. As defined by Wikipedia (2008), videoblogging, shortened as vlogging in this article, is a form of blogging for which the medium is a video.

A videoblog, or vlog, is defined as a blog that uses video as its main source instead of texts. Current videoblogs are essentially text blogs with externally linked videos for each entry (Parker \& Pfeiffer, 2005). Videoblogging offers a richer web experience than typical text blogging because it combines movies, sound, still images, and text, increasing the information-and potentially emotions - shared with users. Most people who have vlogs usually describe various topics such as hobbies, tips, brief speech, and so forth. This is one reason a vlog usually is considered as online diaries.

Those online and orally spoken diaries are the main component of learning target languages. Vlog offers a comfortable and personal site for people to practice the target languages. Doing the videos online offers learners the opportunity to practice their language skills anywhere and with little prior preparation, which keeps them involved in the process (Thomas, 2009). Video blogging or 'vlogging' as part of blogging trend tends to have a positive effect on enhancing learners' fluency, accuracy, and accent or language complexity. Since vlogging is mostly oral, speaking is the major component being emphasized.

Speaking is the heart of learning English. Speaking as one productive skill offers a real result for someone who learns a foreign language. It is considered as the most important skill for business and government officers as it is the main communication tool worldwide. Speaking is extremely important when it comes to the output process of learning second language. Moreover, the teaching and evaluating of speaking is somewhat being ignored. It is also absent from the testing in every foreign language classroom since the objectivity of the testing is rather questioned. It should be raters, not teachers, who evaluate or judge the speaking ability of someone. The goal is the ability of language learners to orally express their ideas. Once speaking goals have been determined, the next step consists of questioning how they are going to be achieved.

According to Johnson and Pearson in Darmiyati (2007, p.16), there are two causes of low Englishspeaking achievement. They usually come from external and internal factors. External factors can be classified into two groups: social and non-social factors. Social factors can come from the students themselves and non-social factors can be the place or location, the weather, and time when the learning process happens. Internal factors can also be classified into two groups. They are physiological factors and psychological factors. The physiological factors include the function of certain organs that students have while the psychological factors can be the students' motivation and interest.

Motivation is one of the internal factors considered very important in teaching and learning process. It assumes that motivation has a great role in determining the success of learning process to reach the goal of learning and the students' activeness. It means that the students with low motivation probably will face difficulties in learning process while students with high motivation or highly motivated students can reach the learning's objectives easily. Highlymotivated students tend to participate actively during learning process. They often ask questions and like to share ideas with their friends.

Based on the explanation above, this study would focus on students to enhance their speaking skill. It also aimsatfinding out howmotivation could influence the learning process. Furthermore, it is expected that vlogging might stimulate students to learn how to speak English by implementingaccurate andproper English grammar, to choose suitable vocabularies, and to create as well as to develop creative ideastowards their speaking activities in everyday classes. 


\section{METHODS}

\section{Research Setting and Participants}

This study was undertaken atPoliteknik Negeri Malang focusing on English department study program. There are three classes in English department and only one class which will randomly be chosen to be the participant of this study. One classroom consists of 25 students. They are considered to have sufficient knowledge and ability in English as reflected from their daily performance score especially in reading and writing activities yet they have problems in speaking. Based on the classroom observation result and interview with the speaking teacher which were done before this study, students seemed reluctant duringthe speaking activities. They showed only little interest during the activities and mostly produced simple and unelaborated sentences. Students also showed less initiative to voluntarily speak up or ask questions.

\section{Techniques of Collecting Data}

This study employed three techniques of collecting data namely classroom observation, questionnaires and interview with the speaking teacher. The observation was carried out to find out students' participations and responses in speaking activities. It was done three times, each after two vlog tasks. Open-ended questionnaires were addressed to the respondents to get their responses in the form of written data. The interview with the speaking teacher was conducted to gain further information on students' motivation and confidence to speak English. The questions revolved around the speaking teacher's observation and evaluation as the classroom teacher and how she perceived students' performance during speaking activities. As for the task for vlog in YouTube Channel, it was given after each unit in the material book was completed. Students were required to make one vlog for one unit/topic of discussion.

\section{RESULTS AND DISCUSSION}

Through classroom observation, it is noticed that students' motivation and confidence gradually improved. It was not yet seen until the second classroom observation that students showed more participation in speaking activities as well as higher responses. They stayed excited throughout the whole speaking activities and spent longer time speaking until the given time by the teacher was up. By the time the last observation was conducted, it was clear that students now were more motivated and confident to speak in the class using English. Regardless the complexity of the activities, the students remained highly participated.

From the open-ended questionnaires distributed to the students at the end of the cycle, most of the students gave positive response towards the use of vlog in YouTube Channel in improving their motivation and confidence. They agreed that the use of vloghelped growing their motivation and confidence to speak English higher. Mostly it wasbecause the tasks were done in the place where they found most comfortable such asin their houses or bedrooms and that they were given enough time to think on what theywanted to say. The questionnaires also revealed that when being given the choice, studentsenjoyed doing vlogging as much as the common speaking activities in the class with theirpeers. Vlog enabled them to speak freely and comfortably without feeling anxious butdoing activities in class with the peers also gave them enjoyable learning moment andinteractions.

Since all of the students recorded the vlogs using their phones and that they were fairly technology savvy, all of them were enthusiastic on the ideas of bringing more technology into classroom activities. For one thing, technology was something that they were familiar with. It was also flexible and a lot more interactive compared to the traditional teaching media.

\section{CONCLUSION}

One goal of any academic program should be to provide a foundation from which students can further develop their own ability to adapt and continue learning on their own (Wu, Yen \& Marek: 2011). In a nutshell, incorporating vlog in YouTube Channel in teaching helped to improve 


\section{Fitrotul Maulidiyah}

students' motivation and confidence of English department students at Politeknik Negeri Malang.Most of the factors which indicated higher motivation and confidence were reflected from the students' response and participation in the classroom. Additionally, the teacher agreed on seeing the improvement of her students' during her teaching session. Bringing technology into teaching and learning process is now proven to be one of the most effective ways to improve students' general performance in quite significant result. For future improvement, the habit of combining technology into one of the teaching techniques used in class should not just stop here. Most importantly, teachers need to be more technology savvy and need to keep up with the advancement of the technology in order to be able to help students to improve their English.

\section{REFERENCES}

Arianingsih, Y. (2005). Hubungan Motivasi Berprestasi Dengan Hasil Belajar Mata Pelajaran Ekonomi Pada Siswa Kelas II SMP Negeri 5 Jambi. A thesis. Universitas Jambi. Unpublished.

Aydin, S. (2014). The use of blogs in learning English as a foreign language. Mevlana International Journal of Education (MIJE), 4(1), pp. 244-259. Retrieved from: http// mije.mevlana.edu.tr/

Berliner, D. C., \& Gage, N. L. (1984). Educational Psychology Third Edition. Boston: Standford University and University of Arizona.

Dornyei, Z. (2003). Attitudes, Orientation and Motivations in Language Learning Advances in Theory, Research and Application. Language Learning. Vo. 52, Supplement 1.

Gao, W., et al. (2010). Vlogging: A Survey ofVideoblogging Technology on the Web. ACMComputing Surveys, (42)4. Pp: $15.1-15.55$.

Gunelius, S. in https://www.lifewire.com/what-is-a-vlog-3476285. Accessed on March 20th 2017.

Juhana (2012). Psychological factors that hinder students from speaking in English class (A case study in a Senior High School in South Tangerang, Banten, Indonesia), Journal of Education and Practice, 3 (12), 100-101.

Karch, M. in https:/ /www.lifewire.com/channel-youtube-1616635. Accessed on March 20th 2017.

Mutmainna, M. (2016). Implementing blogs as a learning tool in ASIAN EFL/ESL learning context. BRAC University Journal, XI(1), 27-35.

Philips, N., \& Lindsay, G. (2006). Motivation in gifted students. High ability studies, 17 (1), 57-72.

Su, Y.C. (2006). EFL teachers' perception of English language policy at the elementary level in Taiwan, Educational Studies, (32) 3 Educational Technology and Society, 265-283.

Wu, W.V., Yen, L.L., Marek, M. (2011). Using Online EFL Interaction to Increase Confidence, Motivation and Ability., 14 (3), 127. 